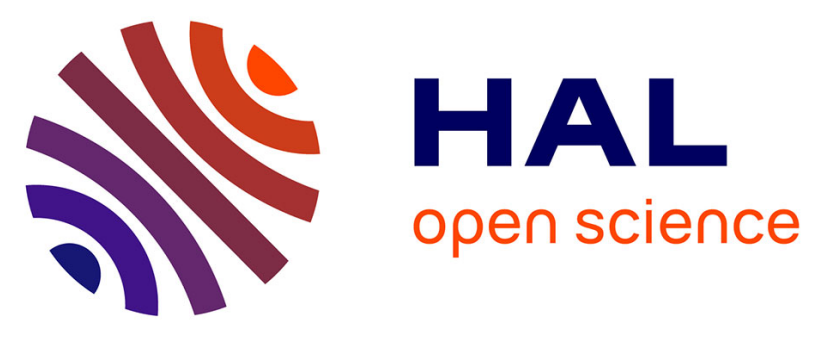

\title{
HIV infection in North African patients
}

Marion Parisey, Françoise Louni, Elisabeth Bouvet, Roland Landman, Charlotte Charpentier, Sylvie Lariven, Véronique Joly, Agnès Villemant, Claude Mackoumbou-Nkouka, Yazdan Yazdanpanah, et al.

\section{- To cite this version:}

Marion Parisey, Françoise Louni, Elisabeth Bouvet, Roland Landman, Charlotte Charpentier, et al.. HIV infection in North African patients. AIDS Research and Human Retroviruses, 2019, 35 (7), pp.628-633. 10.1089/AID.2018.0292 . inserm-02362448

\section{HAL Id: inserm-02362448 https://www.hal.inserm.fr/inserm-02362448}

Submitted on 13 Nov 2019

HAL is a multi-disciplinary open access archive for the deposit and dissemination of scientific research documents, whether they are published or not. The documents may come from teaching and research institutions in France or abroad, or from public or private research centers.
L'archive ouverte pluridisciplinaire HAL, est destinée au dépôt et à la diffusion de documents scientifiques de niveau recherche, publiés ou non, émanant des établissements d'enseignement et de recherche français ou étrangers, des laboratoires publics ou privés. 


\section{Title}

HIV infection in North African patients

\section{Running title}

HIV infection in North African patients

\section{Authors}

Marion Parisey ${ }^{1}$, Françoise Louni ${ }^{2}$, Elisabeth Bouvet ${ }^{1}$, Roland Landman ${ }^{1,3}$, Charlotte

Charpentier $^{4}$, Sylvie Lariven ${ }^{1}$, Véronique Joly ${ }^{1,3}$, Agnès Villemant ${ }^{6}$, Claude MackoumbouNkouka $^{2}$, Yazdan Yazdanpanah ${ }^{1,3}$, Charles Burdet ${ }^{3,5}$

${ }^{1}$ Department of Infectious Diseases, Bichat Hospital, AP-HP, Paris, France

${ }^{2}$ COREVIH Île-de-France Nord, Paris, France

${ }^{3}$ IAME, UMR 1137, INSERM, Université Paris Diderot, Sorbonne Paris Cité, Paris, France

${ }^{4}$ AP-HP, Virology laboratory, Bichat Hospital, AP-HP, Paris, France;

${ }^{5}$ Department of Epidemiology, Biostatistic and Clinical Research, Bichat Hospital, AP-HP, Paris,

France

${ }^{6}$ Department of Internal Medicine, Beaujon Hospital, AP-HP, Clichy, France

\section{Correspondence}

Marion PARISEY

Department of Infectious Diseases, Bichat Hospital, 46 rue Henri Huchard, 75018 Paris, France

Tel +3315727 7535

Email marion.parisey@aphp.fr

\section{Acknowledgments}

We thank all participating patients. The authors thank David Marsh for help in English writing.

\section{Author contributions}


$E B, R L, C C, Y Y, C B$ conceived the study. EB, RL, CC, SL, VJ, AV, YY, CB provided care to patients. FL and CMN performed the data management. CB performed the statistical analysis of the data. MP, CB and $Y Y$ wrote the first draft of the manuscript. All authors reviewed the final version of the manuscript.

\section{Disclosure}

The authors report no conflicts of interest in this work. 


\section{Abstract}

Introduction: North Africa is one of the rare regions where the HIV epidemic is growing. In France, $5 \%$ of the migrants discovering their HIV infection are from North Africa. The objective of this study was to compare the sociodemographic characteristics and outcomes of North African and French HIV-infected patients.

Material and methods: This study was conducted in the HIV clinic of the Bichat Hospital (Paris, France). The North African HIV-infected patients were born in Algeria, Tunisia, or Morocco, or had lived there for more than 6 months. They were matched for age and gender (1:2) to patients born in France who had never lived outside France for more than 6 months. Sociodemographic, clinical, and immunovirological characteristics of North African and French patients were compared using a conditional logistic regression.

Results: Among 4738 eligible patients, 285 North Africans were identified. CD4 levels at HIV diagnosis were not significantly different between North African and French patients, but were more frequently $<200 / \mathrm{mm}^{3}$ in the former than the latter at treatment initiation $(p=0.02)$. CDC-stage 3 disease occurred more frequently in the first three years of care in our centre in North African patients than in French patients $(p=0.01)$ and control of the HIV viral load over the 12 months preceding inclusion was better in French patients $(p=0.0001)$. There was no difference regarding loss to care.

Discussion: These results highlight possible issues in adherence to antiretroviral treatment in North African patients, which may be related to differences in the acceptability of the disease.

Keywords: HIV infection, migrants, North Africa, adherence 


\section{Introduction}

Almost 80 million individuals have been infected by HIV and 35 million deaths have been related to this infection since 1981 (1). In 2017, an estimated 37 million individuals were infected by the virus, most of them living in Africa, and approximately 1.8 million new infections were reported. However, thanks to a vast effort to combat the epidemics, the incidence of HIV infection is decreasing worldwide. This trend reversal was enabled by improvement of diagnostic tools and the development of ever-more powerful antiretroviral drugs and prevention tools. In 2013, UNAIDS called for continuing efforts to end the HIV epidemics and reach an ambitious target by 2020: $90 \%$ of all people living with HIV will know their HIV status, $90 \%$ of all people with diagnosed HIV infection will receive sustained antiretroviral therapy, and $90 \%$ of all people receiving antiretroviral therapy will have viral suppression.

A notable exception to this favorable epidemiology is the Middle East and North Africa (MENA), where HIV infection incidence is growing fast despite the low reported prevalence of HIV infection in the general population in the region (0.1\%) (2). MENA is a large and diverse region constituted by 24 countries or territories with different levels of economic development. An increase in HIV incidence of 26\% was reported there between 2000 and 2015 (3), followed by an increase of AIDS-related deaths: in 2017, as many as 10,000 patients died from HIV-related diseases, corresponding to a 3-fold increase since 2000. Key populations in which HIV epidemics spread have been identified: female sex workers, people who inject drugs (PWID), and men who have sex with men (MSM) $(3,4)$. The main route of HIV transmission appears to be unprotected heterosexual sex: $95 \%$ of new HIV infections in MENA are diagnosed in key populations and their sexual partners (5).

Although many countries of the region have made a significant effort to fight the extension of the epidemics, the lack of a high-quality HIV surveillance system limits understanding of HIV infection epidemiology in MENA, in both the general and high-risk populations (6). In addition, cultural and religious norms put a brake on studies of behavioral and sexual conduct (7). This results in the stigmatization of HIV-infected patients, and in reluctance to access care. Patients' access to 
antiretroviral therapy is low: in 2017 , only $29 \%$ of HIV-infected patients received antiretroviral therapy (1). The epidemiology of HIV infection in North Africa (Algeria, Morocco, and Tunisia) presents the same characteristics as in the rest of MENA, with a concentrated epidemic $(8,9)$.

In France, $48 \%$ of newly diagnosed HIV infections affect patients born abroad, many of whom are from sub-Saharan Africa (33\% in 2014) (10). Because of its size, this population has been extensively studied, thereby highlighting some characteristics: newly diagnosed patients are mainly women, with a more frequently heterosexual route of transmission and a lower rate of CD4 at diagnosis than in infected people born in France. Better understanding of this population has led to improved prevention, screening and support for treatment.

In France, North African people represent $29 \%$ of the whole population born abroad and in $20085 \%$ of patients with a new diagnosis of HIV infection were born in North Africa (11). This population has been little studied (12). We aimed here to describe the demographic, clinical and immunologic characteristics of North African HIV-infected patients in our HIV clinic, and to compare them with those of French patients.

\section{Material and methods}

\section{Population and study design}

We conducted a retrospective study in the HIV clinic at the Bichat Hospital (Paris, France). Patients were eligible if they were above 18 years old, had been diagnosed with HIV-1 infection, and had at least one outpatient visit in our clinic between January $1^{\text {st }} 2015$ and January $31^{\text {st }}$ 2016. Patients were considered to be from North Africa if they were born in Algeria, Morocco, or Tunisia, or if they had lived in one of these 3 countries for more than 6 months. This definition was chosen as the nationality is not the only variable allowing for a good approximation of migrant status $(13,14)$. Previous residence abroad is routinely collected in our center.

All patients gave their written informed consent to have their medical chart recorded in the electronic medical record system Nadis ${ }^{\circledR}$ (www.dataids.org Fedialis Medica, Marly Le Roi, 
France, CNIL number: 1171457, 24 May 2006), designed for the healthcare medical care of HIVinfected patients. Data were anonymized before analysis.

\section{Characteristics studied}

Clinical characteristics studied included sex, age (including age at the diagnosis of HIV infection), transmission route, time between the first positive HIV serology and first consultation at our HIV clinic, time between the first positive HIV and inclusion in the present study, history of tuberculosis, serologic status for B hepatitis and C hepatitis, CDC stage at the study time point and time to occurrence of stage 3 disease. In addition, we defined loss to care as the absence of consultation in our department for more than 12 months.

Transmission route was categorized in three classes (heterosexual, MSM, other), as was the time to occurrence of stage 3 disease (no stage 3 at the study time point, stage 3 occurring within the first 3 years after HIV infection diagnosis, stage 3 occurring more than 3 years after HIV infection diagnosis).

Immunovirological characteristics included CD4 cell count and HIV plasma viral load at HIV diagnosis, before the first antiretroviral treatment and at the last visit, as well as CD4 nadir value. CD4 cell count was dichotomized as $<200 / \mathrm{mm}^{3}$ and $\geq 200 / \mathrm{mm}^{3}$. HIV plasma viral load at diagnosis was dichotomized as $<5 \log _{10} \mathrm{cp} / \mathrm{mL}$ and $\geq 5 \log _{10} \mathrm{cp} / \mathrm{mL}$. HIV plasma viral load was considered to be controlled over the last 12 months if no measurement was above $50 \mathrm{cp} / \mathrm{mL}$ during that time.

Data regarding antiretroviral treatment included the number of treatment lines received by the patient, the duration of the last line of treatment, and the nature of the current antiretroviral therapy. The nature of the current antiretroviral therapy was categorized as 2 nucleoside reversetranscriptase inhibitors (NRTIs) and 1 protease inhibitor (PI), 2 NRTIs and 1 non-nucleoside reverse-transcriptase inhibitor (NNRTI), 2 NRTIs and 1 integrase inhibitor (II), or another strategy. 


\section{Statistical analysis}

We first performed a descriptive analysis of North African patients. Then, we compared the characteristics of North African patients with those of French patients by performing a univariate conditional regression analysis. French patients were defined as HIV-infected patients born in France who never lived outside France for more than six months. They were randomly chosen among patients fulfilling the inclusion criteria described above. Each North African patient was matched to 2 French patients for sex and age (+/- 5 years) using a greedy algorithm (http://mayoresearch.mayo.edu). Variables achieving $\mathrm{P}<0.20$ in the univariate analysis were entered into a multivariate conditional logistic regression analysis to identify characteristics independently associated with North African geographical origin. Using a forward stepwise selection method, we obtained a final model in which all characteristics had a P-value $<0.05$. As a sensitivity analysis, we also performed this comparative analysis in North African patients born outside France.

Descriptive statistics are expressed as number (\%) and median (range), as appropriate. All analyses were performed with SAS v9.4 (SAS Institute Inc., Cary, NC, USA). All tests were twosided with a type-I error set to 0.05 .

\section{Results}

\section{North African patients' characteristics}

Among 4738 patients seen in consultation between January $1^{\text {st }} 2015$ and January $31^{\text {st }} 2016$ in our clinic, 285 were from North Africa. Their characteristics are presented in Table 1. Included North African patients were born in Algeria (108, 46.2\%), Morocco (86, 36.8\%), Tunisia (27, $11.2 \%)$ or France $(13,5.6 \%)$. Among the 13 patients born in France, North African origin was related to a >6-month stay in Algeria for 9 patients, in Morocco for 3 patients, and in Tunisia for 1 patient. 
Median age of North African patients was 54.7 years $(22.9 ; 85.5)$, and 203 were men $(71.2 \%)$. In one patient, the infection was diagnosed before the age of 18 years. HIV infection was related to heterosexual relations in half of the patients included $(n=139,49.5 \%)$, and 39 patients $(11.4 \%)$ were intravenous drug users. Median age at diagnosis of HIV infection was 35.7 years $(9.4 ; 75.8)$, and HIV infection was diagnosed for $16.3(0.0 ; 32.9)$ years. A history of tuberculosis was reported in 38 patients $(13.3 \%)$ and $35(12.3 \%)$ had a history of HCV infection. Half of the patients included had a CDC stage 1 disease $(n=135,50.0 \%)$, and approximately one-third $(n=93,34.4 \%)$ were stage 3 . Among them, CDC stage 3 occurred within the first 3 years after the diagnosis in 53 patients (19.7\%) and more than 3 years after the diagnosis of HIV infection in 39 patients (14.5\%). The CD4 cell count at the diagnosis was below $200 / \mathrm{mm}^{3}$ in 98 patients $(34.4 \%)$. The median time between the diagnosis of HIV infection and the beginning of antiretroviral treatment was 1.0 year $(0.0 ; 27.5)$. The median number of treatment lines was 5 , ranging from 1 to 26 . The last antiretroviral therapy included $2 \mathrm{NRTIs}+1 \mathrm{PI}$ in 93 patients (33.7\%), $2 \mathrm{NRTIs}+1 \mathrm{NNRTI}$ in $80(29.0 \%), 2$ NRTIs +1 II in $55(19.9 \%)$ or another regimen in $48(17.4 \%)$. This treatment was administered to patients for a median time of 3.3 years $(0.5 ; 16.1)$. Twenty patients $(7.1 \%)$ were lost to care.

\section{Comparative analysis}

Of the 285 patients who were North African, 265 could be matched to 2 French patients and 20 could be matched only to 1 French patient according to sex and age (+/- 5 years). Results of the univariate and multivariate analyses of characteristics associated with a North African origin are reported in Table 1.

In the univariate analysis, patients from North Africa had a higher age at HIV diagnosis than French patients: 35.7 years $(9.4 ; 75.8)$ vs 33.4 years $(0.0 ; 74.8), p<0.0001$. They reported less frequently an MSM route of HIV transmission (24.6\% vs $47.5 \%, p<0.0001)$. North African patients more frequently had a history of tuberculosis $(13.3 \%$ vs $6.9 \%, p=0.005)$. Although there was no between-group difference in the proportions of patients with stage 3 disease, when it arose stage 3 occurred more frequently in the first 3 years after HIV diagnosis in North African patients than in 
French patients $(19.7 \%$ vs $12.1 \%, p=0.01)$. The CD4 cell count of North African patients at diagnosis of the infection was not significantly different from that of French patients $(34.4 \%$ vs $30.7 \%, p=0.2$ ), but was significantly more frequently below $200 / \mathrm{mm}^{3}$ at the time of antiretroviral therapy initiation $(47.7 \%$ vs $37.7 \%, p=0.008)$. Control of HIV viral load differed significantly between groups over the last 12 months before inclusion in the study: 77 (27.0\%) North African patients had at least $1 \mathrm{HIV}$ viral load above $50 \mathrm{cp} / \mathrm{mL}$ vs $56(11.5 \%)$ French patients $(p<0.0001)$. North African patients had received fewer lines of antiretroviral therapy $(5[1 ; 26]$ vs. $6[1 ; 43]$, $\mathrm{p}=0.0005)$ and received their current treatment line for a longer time than French patients (3.3 years $[0.5 ; 16.1]$ vs 2.4 years $[0.5 ; 19.6], p=0.01)$. There was no between-group difference in terms of loss to care.

Because of some missing characteristics, the multivariate analysis was performed in 628 patients, 218 of whom were North African. In the multivariate analysis, North African patients more frequently had a history of tuberculosis $(\mathrm{OR}=2.5,95 \% \mathrm{Cl}, 1.2-5.2)$ and a shorter care duration in our centre $(\mathrm{OR}=0.95 ; 95 \% \mathrm{Cl}, 0.92 ; 0.98)$. An MSM route of transmission was less likely to be reported $(\mathrm{OR}=0.2 ; 95 \% \mathrm{Cl}, 0.1-0.4)$. The $\mathrm{CD} 4$ cell count at the time of antiretroviral initiation was more frequently below $200 / \mathrm{mm}^{3}(\mathrm{OR}=1.6$; $95 \% \mathrm{Cl}, 1.0-2.4)$ and the HIV viral load was less likely to be controlled over the last 12 months $(\mathrm{OR}=2.4 ; 95 \% \mathrm{Cl}, 1.3-4.2)$. Full results are presented in Table 1. Similar results were obtained when excluding North African patients born in France.

\section{Discussion}

Our study highlights the characteristics of North African patients infected by HIV and living in France. This is the first study focusing on this population, although North African people living in France represent $2.6 \%$ of the total French population (11).

Migrants constitute a population at high risk of HIV infection $(15,16)$. Until 2007 in France, new HIV infections were mainly diagnosed in migrants, predominantly from sub-Saharan Africa (15). The numerous studies carried out in this population unraveled their characteristics and helped improve their care (15-17). We currently lack similar studies in North Africans, though such 
people represent a substantial proportion of French migrants and come from countries where the HIV epidemic is growing fast.

The main result of our study is that North African patients had a lower CD4 count at initiation of treatment, although they were diagnosed at the same stage as patients from France. They also more frequently had a detectable HIV viral load over the 12 months preceding inclusion in the study. This could result from a reluctance to begin antiretroviral therapy and from difficulty adhering to antiretroviral treatment.

Three moments are probably key in the trajectory of care for an HIV-positive person: access to the healthcare system after diagnosis, initiation of treatment, and retention in the healthcare system. The real challenge is to understand people's reluctance to start treatment once the infection is diagnosed (18). Our results may be related to cultural and social differences in selfrepresentation in North African patients. The fear of being judged within the healthcare system is a first obstacle. A study carried out in Iran revealed that HIV-infected patients experienced negative feelings from healthcare workers (19). These feelings were responsible for a lack of adherence to treatment and suboptimal care. The fear of being stigmatized by friends and family is another issue faced by patients in such countries $(20,21)$.

Social acceptance of HIV infection among North African migrants living in France was studied at the end of 1990 (22). HIV infection is associated with illegitimate relationships and inappropriate behavior. This vision might hinder the acceptance of HIV infection and thereby delay treatment initiation, and lead to imperfect follow-up and retention in care. Many patients who are North African continue to live with their family and consider that taking antiretroviral therapy may increase the stigma (22).

In our study, approximately $70 \%$ of North African patients were men and the proportion of MSM was lower in North African patients than in French patients (24.6\% vs $47.5 \%$ ). In France, in 2015, most HIV-infected patients were male $(68.3 \%)$, a percentage that had not changed since 2012 (23). The main reported risk group was MSM (43\%), a percentage similar to that observed in the French patients included in the present analysis. The data collected for MENA show that the leading reported mode of transmission in HIV patients was heterosexual. The second most 
reported mode of transmission was 'unknown', suggesting in some cases a concealed transmission by homosexual intercourse (24).

In North Africa, existing data report that men are more frequently affected than women, probably due to riskier behaviors in men than in women, such as unprotected sexual relationships or use of intravenous drugs $(25,26)$. Over the last few years, however, there had been a feminization of the epidemic, with more HIV infection in women (27-29). In North Africa, heterosexual relations constitute the main route of transmission reported both for men and women (3); reported MSM route of transmission is less frequent (21\% in Morocco, $12 \%$ in Algeria, and $2 \%$ in Tunisia). This is in line with our results, although some men may not declare their homosexual relations. This self-report bias might be more frequent in patients from North Africa than in French patients (2).

People who inject drugs play an important role in HIV transmission in MENA. In addition to sharing non-sterile equipment with other drugs users, they tend to display more risky sexual behavior, such as unprotected sex and multiple partners (30). In our population of North Africans, only $13.4 \%$ reported using intravenous drugs.

Results of previous studies analyzing characteristics of HIV-infected sub-Saharan African migrants highlighted points in common and differences with migrants from North Africa. Modes of transmission appear to be very similar in these 2 groups of patients, being mainly heterosexual relationships (16). However, newly HIV-infected patients are mostly women among sub-Saharan migrants, and mostly men among North African migrants (15-17). North African migrants had a CD4 count at diagnosis similar to that of French patients, in contrast to patients from sub-Saharan Africa in whom the infection was diagnosed at a more advanced stage of the disease.

Our study has some limitations. Some data, like the mode of transmission, were selfreported and may be subject to bias. Regarding the definition of North African patients, our database lacked information on the time between emigration from North Africa and seroconversion. However, our study provides a first insight into the North African population of HIV-infected patients in France, and our results highlight important characteristics for optimal care. 
Studying the characteristics of North African patients is an additional tool in the global fight against HIV infection. Based on our results, in France, the challenge in North African patients is to increase adherence to care once the infection is diagnosed, in order to reduce at an individual level rapid progression to an advanced stage of the disease and to improve long-term adherence. At a population level this will also allow a decrease in HIV transmission. Cohort studies including sociological analysis are needed to confirm our results. In addition, future studies ought to analyze differences between patients newly arrived in France and those who have been in France for a long time (sometimes since childhood).

\section{References}

1. UNAIDS. Fact sheet 2018 - Latest statistics on the status of the AIDS epidemic. Available from: http://www.unaids.org/sites/default/files/media asset/UNAIDS FactSheet fr.pdf. Accessed October 30, 2018.

2. UNAIDS. Middle East and North Africa Regional report on AIDS 2011. Available from: http://www.unaids.org/sites/default/files/media asset/JC2257 UNAIDS-MENA-report2011 en 3.pdf. Accessed October 30, 2018.

3. UNAIDS. How AIDS changed everything - MDG6: 15 years, 15 lessons of hope from $\begin{array}{llll}\text { the } & \text { AIDS } & \text { Available }\end{array}$ http://www.unaids.org/sites/default/files/media asset/MDG6Report en.pdf. Accessed October 30, 2018.

4. Gokengin D, Doroudi F, Tohme J, Collins B, Madani N. HIV/AIDS: trends in the Middle East and North Africa region. International journal of infectious diseases : IJID : official publication of the International Society for Infectious Diseases. 2016 Mar;44:66-73.

5. Bozicevic I, Riedner G, Haghdoost A. HIV case reporting in the countries of North Africa and the Middle East. Journal of the International AIDS Society. 2014;17:18962.

6. Shawky S, Soliman C, Kassak KM, Oraby D, EI-Khoury D, Kabore I. HIV surveillance and epidemic profile in the Middle East and North Africa. Journal of acquired immune deficiency syndromes. 2009 Jul 1;51 Suppl 3:S83-95. 
7. Kamarulzaman A. Fighting the HIV epidemic in the Islamic world. Lancet. 2013 Jun 15;381(9883):2058-60 .

8. Kouyoumjian SP, El Rhilani H, Latifi A, El Kettani A, Chemaitelly H, Alami K, et al. Mapping of new HIV infections in Morocco and impact of select interventions. International journal of infectious diseases. 2018 Mar;68:4-12.

9. Mumtaz GR, Awad SF, Feizzadeh A, Weiss HA, Abu-Raddad LJ. HIV incidence among people who inject drugs in the Middle East and North Africa: mathematical modelling analysis. Journal of the International AIDS Society. 2018 Mar;21(3):e25102.

10. Institut de Veille Sanitaire. Découvertes de séropositivité VIH et de Sida. Point épidémiologique au $\quad$ er avril 2016. Available from: http://invs.santepubliquefrance.fr/fr../content/download/124392/441812/version/3/file/Surveillance VihSida2003 2014.pdf. Accessed October 30, 2018b.

11. Brutel C. L'analyse des flux migratoires entre la France et l'étranger entre 2006 et 2013, Available from: https://www.insee.fr/fr/statistiques/1521331. Accessed October 30, 2018.

12. Institut de Veille Sanitaire. Les découvertes de séropositivité VIH chez les migrants en France, 2009. Available from: http://www.corevih-idfnord.fr/wpcontent/uploads/2011/02/11 2009.11.19 INVS vih migrants.pdf. Accessed October 30, 2018.

13. Del Amo J, Broring G, Hamers FF, Infuso A, Fenton K. Monitoring HIV/AIDS in Europe's migrant communities and ethnic minorities. Aids. 2004 Sep 24;18(14):1867-73.

14. Lanoy E, Mary-Krause M, Tattevin P, Perbost I, Poizot-Martin I, Dupont C, et al. Frequency, determinants and consequences of delayed access to care for HIV infection in France. Antiviral therapy. 2007;12(1):89-96.

15. Institut de Veille Sanitaire. Les découvertes de séropositivité VIH chez les migrants en $\begin{array}{llll}\text { France, } & 2016 . & \text { Available } & \text { from: }\end{array}$ http://invs.santepubliquefrance.fr/content/download/128427/458138/version/1/file/decouvertes vi h migrants 2014.pdf. Accessed October 30, 2018.

16. Desgrées de Loù A. Les immigrés face au VIH. Questions de Santé Publique. 2014;24. 
17. Lert F, Annequin M, Tron L, Aubrière C, hamelin C, Spire B, et al. Socioeconomic conditions of people living with HIV followed at hospital in metropolitan France. Results of the ANRS-VESPA2 study. BEH. 2013;26-27:298-9.

18. Desgrées de Loù A, Pannetier J, Ravalihasy A, Gosselin A, Supervie V, Panjo H, et al. Sub-Saharan African migrants followed-up for HIV infection in France: how many acquired HIV after migration? Estimations from the ANRS-PARCOURS Study. 2015;40-41:752-8.

19. Rahmati-Najarkolaei F, Niknami S, Aminshokravi F, Bazargan M, Ahmadi F, Hadjizadeh E, et al. Experiences of stigma in healthcare settings among adults living with HIV in the Islamic Republic of Iran. Journal of the International AIDS Society. 2010 Jul 22;13:27.

20. Kabbash IA, El-Gueneidy M, Sharaf AY, Hassan NM, Al-Nawawy N. Needs assessment and coping strategies of persons infected with HIV in Egypt. Eastern Mediterranean health journal = La revue de sante de la Mediterranee orientale = al-Majallah al-sihhiyah li-sharq al-mutawassit. 2008 Nov-Dec;14(6):1308-20.

21. Karamouzian M, Akbari M, Haghdoost AA, Setayesh H, Zolala F. "I am dead to them": HIV-related stigma experienced by people living with HIV in Kerman, Iran. The Journal of the Association of Nurses in AIDS Care : JANAC. 2015 Jan-Feb;26(1):46-56.

22. UNAIDS. Fast track: Ending the AIDS epidemic by 2030. Available from: http://www.unaids.org/en/resources/documents/2014/fast track. Accessed October 30, 2018.

23. Cherabi K, Fanget D. Le VIH/Sida En Milieu Migrant Arabo-Musulman En France. 1997. Available from: http://hivhealthclearinghouse.unesco.org/sites/default/files/resources/bie arcat vihmigrantsmusul mans fr.pdf. Accessed October 30, 2018.

24. Bozicevic I, Riedner G, Calleja JM. HIV surveillance in MENA: recent developments and results. Sexually transmitted infections. 2013 Nov;89 Suppl 3:iii11-6.

25. Morlat P. Prise en charge médicale des personnes vivant avec le VIH. Epidémiologie de l'infection à VIH en France (juillet 2017). Conseil national du sida et des hépatites virales. 2017.

26. Institut de Veille Sanitaire. Découvertes de séropositivité VIH et de Sida, mars 2017. Available from: 
http://invs.santepubliquefrance.fr/content/download/135287/485871/version/4/file/SurveillanceVIH Sida2003 2015.pdf. Accessed October 30, 2018.

27. République de Tunisie. Rapport d'Activité sur la Riposte au SIDA, Tunisie 2012-2013. Available from: http://www.unaids.org/sites/default/files/country/documents//file\%2C94767\%2Cfr..pdf. Accessed October 30, 2018.

28. République algérienne démocratique et populaire. Rapport d'activité sur la riposte nationale au VIH/Sida en Algérie, 2012-2013. Available from: http://www.unaids.org/sites/default/files/country/documents//file\%2C94492\%2Cfr..pdf. Accessed October 30, 2018.

29. Royaume du Maroc. Enquête Nationale à Indicateurs Multiples et Santé des Jeunes, 2006-2007. Available from: http://www.sante.gov.ma/Publications/Etudes enquete/Documents/ENIMSJ \%20Rapport\%20fina I.pdf. Accessed October 30, 2018.

30. Mumtaz GR, Weiss HA, Thomas SL, Riome S, Setayesh H, Riedner G, et al. HIV among people who inject drugs in the Middle East and North Africa: systematic review and data synthesis. PLoS Medicine. 2014 Jun;11(6):e1001663. 
Table 1 Description of the HIV-1 infected patients from North Africa or France included in the study, and characteristics associated with the geographical origin identified by univariate and multivariate analysis.

\begin{tabular}{|c|c|c|c|c|c|c|}
\hline \multirow{2}{*}{$\begin{array}{c}\text { Characteristic } \\
\mathrm{n}(\%) \text { or median (min; max) }\end{array}$} & \multicolumn{2}{|c|}{ Geographical origin } & \multicolumn{2}{|c|}{ Univariate analysis } & \multicolumn{2}{|c|}{ Multivariate analysis } \\
\hline & $\begin{array}{c}\text { North Africa } \\
(n=285)\end{array}$ & $\begin{array}{l}\text { France } \\
(\mathrm{n}=550)\end{array}$ & OR $(95 \% \mathrm{Cl})$ & P-value & OR (95\% Cl) & P-value \\
\hline Age at HIV diagnosis (years) & $35.7(9.4 ; 75.8)$ & $33.4(0.0 ; 74.8)$ & $1.1(1.03 ; 1.07)$ & $<0.0001$ & & \\
\hline History of tuberculosis & $38(13.3)$ & $38(6.9)$ & $2.0(1.2 ; 3.3)$ & 0.005 & $2.5(1.2 ; 5.2)$ & 0.01 \\
\hline Positive HCV serology & $35(12.3)$ & $79(14.4)$ & $0.8(0.5 ; 1.3)$ & 0.4 & & \\
\hline Chronic HBV infection & $7(2.5)$ & $9(1.6)$ & $1.6(0.6 ; 4.2)$ & 0.4 & & \\
\hline $\begin{array}{l}\text { Transmission category } \\
\text { - heterosexual } \\
\text { - MSM } \\
\text { - other }\end{array}$ & $\begin{array}{c}139(49.5) \\
69(24.6) \\
73(26)\end{array}$ & $\begin{array}{l}170(31.0) \\
261(47.5) \\
118(21.5)\end{array}$ & $\begin{array}{c}\text { reference } \\
0.2(0.1 ; 0.3) \\
0.6(0.4 ; 1.0)\end{array}$ & $\begin{array}{c}- \\
<.0001 \\
0.03\end{array}$ & $\begin{array}{c}\text { reference } \\
0.2(0.1 ; 0.4) \\
0.7(0.4 ; 1.2)\end{array}$ & $\begin{array}{c}- \\
<.0001 \\
0.2\end{array}$ \\
\hline Time since HIV diagnosis (years) & $16.3(0.0 ; 32.9)$ & $19.6(0.1 ; 32.2)$ & $\begin{array}{l}0.95(0.94 \\
0.97)\end{array}$ & $<.0001$ & & \\
\hline Time between HIV diagnosis and first consultation (years) & $0.8(-1.2 ; 27.4)$ & $1.4(-2.1 ; 28.8)$ & $1.0(0.9 ; 1.0)$ & 0.3 & & \\
\hline $\begin{array}{l}\text { CDC stage } \\
-1 \\
-2 \\
-3\end{array}$ & $\begin{array}{l}135(50) \\
42(15.6) \\
93(34.4)\end{array}$ & $\begin{array}{l}262(51.1) \\
106(20.7) \\
145(28.3)\end{array}$ & $\begin{array}{c}\text { reference } \\
0.8(0.5 ; 1.2) \\
1.2(0.8 ; 1.7)\end{array}$ & $\begin{array}{l}- \\
0.3 \\
0.4\end{array}$ & & \\
\hline $\begin{array}{l}\text { Time to occurrence of stage } 3 \text { disease } \\
\text { - no stage } 3 \\
\text { - stage } 3 \text { within the first } 3 \text { years } \\
\text { - stage } 3 \text { more than } 3 \text { years after HIV diagnosis }\end{array}$ & $\begin{array}{l}177(65.8) \\
53(19.7) \\
39(14.5)\end{array}$ & $\begin{array}{l}368(71.9) \\
62(12.1) \\
82(16.0)\end{array}$ & $\begin{array}{c}\text { reference } \\
1.8(1.1 ; 2.8) \\
0.9(0.6 ; 1.4)\end{array}$ & $\begin{array}{l}- \\
0.01 \\
0.7\end{array}$ & & \\
\hline Nadir of CD4 cell count $<200 / \mathrm{mm}^{3}$ & $143(50.2)$ & $254(53.7)$ & $0.9(0.7 ; 1.2)$ & 0.6 & & \\
\hline CD4 cell count at diagnosis $<200 / \mathrm{mm}^{3}$ & $98(34.4)$ & $145(30.7)$ & $1.2(0.9 ; 1.7)$ & 0.2 & & \\
\hline HIV viral load at diagnosis $<5 \log _{10} \mathrm{cp} / \mathrm{mL}$ & $85(29.9)$ & $162(29.7)$ & $1.0(0.7 ; 1.4)$ & 0.9 & & \\
\hline CD4 cell count at treatment initiation $<200 / \mathrm{mm}^{3}$ & $104(47.7)$ & $170(37.7)$ & $1.7(1.1 ; 2.4)$ & 0.008 & $1.6(1.0 ; 2.4)$ & 0.05 \\
\hline
\end{tabular}


HIV viral load at treatment initiation $\left(\log _{10} \mathrm{cp} / \mathrm{mL}\right)$

CD4 cell count at last visit $<200 / \mathrm{mm}^{3}$

HIV viral load not controlled over the last 12 months

Number of antiretroviral treatment lines

Last antiretroviral therapy

- 2 NRTIs + 1 PI

-2 NRTIs + 1 NNRT

- 2 NRTIS + 1 INSTI

- other

Time with last antiretroviral therapy (years)

Duration of care in our centre (years)

Lost to care

\begin{tabular}{cccccc}
$4.8(1.3 ; 6.8)$ & $4.9(1.3 ; 8.1)$ & $1.0(0.8 ; 1.3)$ & 0.7 & & \\
$10(3.8)$ & $22(4.2)$ & $0.9(0.4 ; 2.1)$ & 0.9 & & \\
$77(27.0)$ & $56(11.5)$ & $2.9(1.9 ; 4.4)$ & $<0.0001$ & $2.4(1.3 ; 4.2)$ & 0.004 \\
$5(1 ; 26)$ & $6(1 ; 43)$ & $0.9(0.9 ; 1.0)$ & 0.0005 & & \\
& & & & & \\
$93(33.7)$ & $120(24.4)$ & reference & - & & \\
$80(29)$ & $133(27.0)$ & $0.8(0.6 ; 1.3)$ & 0.4 & & \\
$55(19.9)$ & $81(16.5)$ & $0.9(0.6 ; 1.4)$ & 0.7 & & \\
$48(17.4)$ & $158(32.1)$ & $0.4(0.2 ; 0.6)$ & $<0.0001$ & & \\
$3.3(0.5 ; 16.1)$ & $2.4(0.5 ; 19.6)$ & $1.1(1.0 ; 1.1)$ & 0.01 & & \\
$9.3(0.0 ; 24.1)$ & $15.3(0.0 ; 29.5)$ & $1.0(0.9 ; 1.0)$ & 0.0001 & $0.9(0.9 ; 1.0)$ & 0.003 \\
$20(7.1)$ & $34(6.2)$ & $1.2(0.6 ; 2.1)$ & 0.6 & & \\
\hline
\end{tabular}

Notes: Percentages and medians are calculated based on available data. Because of missing characteristics, the multivariate analysis was performed in 606 patients.

Abbreviations: HBV, hepatitis B virus; HCV, hepatitis C virus; MSM, men who have sex with men; NNRTI, non-nucleoside reverse transcriptase inhibitor; NRTI, nucleoside reverse transcriptase inhibitors; PI, protease inhibitor. 
Supplementary Table 1 Description of the HIV-1 infected patients from North Africa or France included in the study, and characteristics

associated with the geographical origin identified by univariate and multivariate analysis. Definition of North African origin was restricted to patients

born in North African country.

\begin{tabular}{|c|c|c|c|c|c|c|}
\hline \multirow{2}{*}{$\begin{array}{c}\text { Characteristic } \\
\mathrm{n}(\%) \text { or median (min; max) }\end{array}$} & \multicolumn{2}{|c|}{ Geographical origin } & \multicolumn{2}{|c|}{ Univariate analysis } & \multicolumn{2}{|c|}{ Multivariate analysis } \\
\hline & $\begin{array}{l}\text { North Africa } \\
(n=272)\end{array}$ & $\begin{array}{c}\text { France } \\
(n=524)\end{array}$ & OR (95\% Cl) & P-value & OR (95\% Cl) & P-value \\
\hline Age at HIV diagnosis (years) & $36.2(9.4 ; 75.8)$ & $33.7(0.0 ; 74.8)$ & $1.1(1.0 ; 1.1)$ & $<0.0001$ & & \\
\hline History of tuberculosis & $36(13.2)$ & $34(6.5)$ & $2.1(1.3 ; 3.8)$ & 0.004 & $2.4(1.2 ; 5.0)$ & 0.02 \\
\hline Positive HCV serology & $30(11.0)$ & $71(13.6)$ & $0.8(0.5 ; 1.2)$ & 0.3 & & \\
\hline Chronic HBV infection & $6(2.2)$ & $9(1.7)$ & $1.3(0.5 ; 3.7)$ & 0.6 & & \\
\hline $\begin{array}{l}\text { Transmission category } \\
\text { - heterosexual }\end{array}$ & $135(50.4)$ & $165(31.6)$ & reference & - & reference & - \\
\hline - MSM & $67(25)$ & $249(47.6)$ & $0.2(0.1 ; 0.3)$ & $<0.0001$ & $0.2(0.1 ; 0.4)$ & $\begin{array}{c}<0.000 \\
1\end{array}$ \\
\hline - other & $66(24.6)$ & $109(20.8)$ & $0.6(0.4 ; 0.9)$ & 0.02 & $0.7(0.4 ; 1.2)$ & 0.2 \\
\hline Time since HIV diagnosis (years) & $16.3(0.0 ; 32.9)$ & $19.5(0.1 ; 31.2)$ & $0.9(0.9 ; 1.0)$ & $<0.0001$ & & \\
\hline Time between HIV diagnosis and first consultation (years) & $0.73(-1.2 ; 27.4)$ & $1.3(-2.1 ; 28.8)$ & $1.0(0.9 ; 1.0)$ & 0.2 & & \\
\hline $\begin{array}{l}\text { CDC stage } \\
-1 \\
-2 \\
-3\end{array}$ & $\begin{array}{l}130(50.6) \\
39(15.2) \\
88(34.2)\end{array}$ & $\begin{array}{l}250(50.9) \\
104(21.2) \\
137(27.9)\end{array}$ & $\begin{array}{c}\text { reference } \\
0.7(0.5 ; 1.1) \\
1.2(0.8 ; 1.7)\end{array}$ & $\begin{array}{l}- \\
0.2 \\
0.4\end{array}$ & & \\
\hline $\begin{array}{l}\text { Time to occurrence of stage } 3 \text { disease } \\
\text { - no stage } 3 \\
\text { - stage } 3 \text { within the first } 3 \text { years } \\
\text { - stage } 3 \text { more than } 3 \text { years after HIV diagnosis }\end{array}$ & $\begin{array}{l}169(66.0) \\
50(19.5) \\
37(14.5)\end{array}$ & $\begin{array}{l}354(72.2) \\
61(12.5) \\
75(15.3)\end{array}$ & $\begin{array}{c}\text { reference } \\
1.7(1.1 ; 2.7) \\
0.9(0.6 ; 1.5)\end{array}$ & $\begin{array}{c}- \\
0.02 \\
0.8\end{array}$ & & \\
\hline Nadir of CD4 cell count $<200 / \mathrm{mm}^{3}$ & $134(49.3)$ & $244(54.1)$ & $0.9(0.6 ; 1.2)$ & 0.4 & & \\
\hline CD4 cell count at diagnosis $<200 / \mathrm{mm}^{3}$ & $92(33.8)$ & $140(31.0)$ & $1.2(0.9 ; 1.6)$ & 0.3 & & \\
\hline HIV viral load at diagnosis $<5 \log _{10} \mathrm{cp} / \mathrm{mL}$ & $191(70.5)$ & $366(70.5)$ & $1.0(0.7 ; 1.4)$ & $>0.9$ & & \\
\hline
\end{tabular}


CD4 cell count at treatment initiation $<200 / \mathrm{mm}^{3}$

HIV viral load at treatment initiation $\left(\log _{10} \mathrm{cp} / \mathrm{mL}\right.$ )

CD4 cell count at last visit $<200 / \mathrm{mm}^{3}$

HIV viral load not controlled over the last 12 months

\begin{tabular}{|c|c|c|c|c|c|}
\hline $99(47.6)$ & $161(37.4)$ & $1.7(1.1 ; 2.5)$ & 0.008 & $1.6(1.0 ; 2.6)$ & 0.04 \\
\hline $4.7(1.3,6.8)$ & $4.9(1.3 ; 8.1)$ & $1.0(0.8 ; 1.3)$ & 0.8 & & \\
\hline $10(4.0)$ & $22(4.4)$ & $0.9(0.4 ; 2.1)$ & 0.9 & & \\
\hline $73(26.8)$ & $53(11.5)$ & $2.9(1.9 ; 4.4)$ & $<0.0001$ & $2.3(1.3 ; 4.1)$ & 0.005 \\
\hline $5(1 ; 26)$ & $6(1 ; 43)$ & $0.9(0.9 ; 1.0)$ & 0.001 & & \\
\hline $\begin{array}{l}90(34.2) \\
76(28.9) \\
52(19.8) \\
45(17.1)\end{array}$ & $\begin{array}{c}110(23.6) \\
126(27.0) \\
80(17.1) \\
151(32.3)\end{array}$ & $\begin{array}{c}\text { reference } \\
0.8(0.5 ; 1.2) \\
0.8(0.5 ; 1.3) \\
0.3(0.2 ; 0.6)\end{array}$ & $\begin{array}{c}- \\
0.3 \\
0.4 \\
<0.0001\end{array}$ & & \\
\hline $3.2(0.5 ; 16.1)$ & $2.4(0.5 ; 19.6)$ & $1.1(1.0 ; 1.1)$ & 0.02 & & \\
\hline $9.3(0.0 ; 24.1)$ & $15.4(0.0 ; 29.5)$ & $\begin{array}{c}0.96(0.94 \\
0.98)\end{array}$ & 0.0001 & $\begin{array}{c}0.96(0.93 \\
0.99)\end{array}$ & 0.008 \\
\hline $20(7.4)$ & $32(6.1)$ & $1.3(0.7 ; 2.3)$ & 0.5 & & \\
\hline
\end{tabular}

Number of antiretroviral treatment lines

Last antiretroviral therapy

-2 NRTIS + 1 PI

-2 NRTIs + 1 NNRTI

- 2 NRTIS + 1 INSTI

- other

Time with last antiretroviral therapy (years)

Duration of care in our centre (years)

$20(7.4) \quad 32(6.1)$

$1.3(0.7 ; 2.3)$

0.5

Notes: Percentages and medians are calculated based on available data. Because of missing characteristics, the multivariate analysis was performed in 606 patients.

Abbreviations: HBV, hepatitis B virus; HCV, hepatitis C virus; MSM, men who have sex with men; NNRTI, non-nucleoside reverse transcriptase inhibitor; NRTI, nucleoside reverse transcriptase inhibitors; PI, protease inhibitor. 